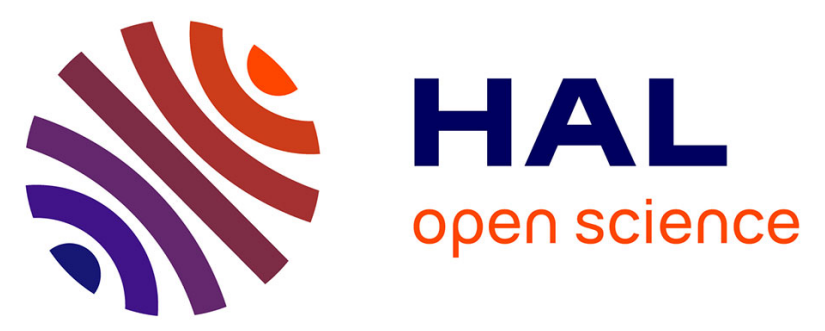

\title{
Malnutrition with hypoaminoacidemia in a 22-year-old pregnant patient masking a likely ornithine transcarbamylase deficiency
}

B. Lefrère, G. Ulmann, M. Chartier, J. Patkaï, L. Cynober, N. Neveux

\section{- To cite this version:}

B. Lefrère, G. Ulmann, M. Chartier, J. Patkaï, L. Cynober, et al.. Malnutrition with hypoaminoacidemia in a 22-year-old pregnant patient masking a likely ornithine transcarbamylase deficiency. Clinical Nutrition ESPEN, 2019, 30, pp.89 - 93. 10.1016/j.clnesp.2019.02.001 . hal-03486593

\section{HAL Id: hal-03486593 \\ https://hal.science/hal-03486593}

Submitted on 20 Dec 2021

HAL is a multi-disciplinary open access archive for the deposit and dissemination of scientific research documents, whether they are published or not. The documents may come from teaching and research institutions in France or abroad, or from public or private research centers.
L'archive ouverte pluridisciplinaire HAL, est destinée au dépôt et à la diffusion de documents scientifiques de niveau recherche, publiés ou non, émanant des établissements d'enseignement et de recherche français ou étrangers, des laboratoires publics ou privés.

\section{(c) (1) $\$$}

Distributed under a Creative Commons Attribution - NonCommerciall 4.0 International 
Version of Record: https://www.sciencedirect.com/science/article/pii/S2405457718304005

Manuscript_5f1ebdbbac2fcf8bd8c4df30c7094506

1 Case-report - Clinical nutrition ESPEN.

05.11 .18

2

3

Title page

4

5 Malnutrition with hypoaminoacidemia in a 22-year-old pregnant patient masking an ornithine

6

transcarbamylase deficiency.

7

8

B. Lefrère ${ }^{\mathrm{a}^{*}}$, G. Ulmann ${ }^{\mathrm{a}, \mathrm{b}}$, M. Chartier ${ }^{\mathrm{c}}$, J. Patkai ${ }^{\mathrm{d}}$, L. Cynober ${ }^{\mathrm{a}, \mathrm{b}}$, N. Neveux ${ }^{\mathrm{a}, \mathrm{b}}$

9

$10{ }^{\text {a }}$ Clinical Chemistry Laboratory, Cochin Hospital, 27 rue du Faubourg Saint-Jacques, AP-HP, Paris, France

$11{ }^{\mathrm{b}}$ Laboratory of Biological Nutrition, EA 4466, Faculty of Pharmacy, 4 avenue de l'Observatoire, Paris Descartes 12 University

$13{ }^{\mathrm{c}}$ Department of Obstetrics, Cochin Hospital, AP-HP, 27 rue du Faubourg Saint-Jacques, Paris, France

$14{ }^{\mathrm{d}}$ Department of Neonatology, Cochin Hospital, AP-HP, 27 rue du Faubourg Saint-Jacques, Paris, France. 15

16

* Corresponding author: bertrand.lefrere@ aphp.fr

17

18

19

20

21

22

23

24

25

26

27

28

29

30

31

32

33

34

35

36

37

38

39

40 


\section{Background}

Symptoms and clinical presentations of OTC deficiency vary widely according to the remaining activity of the enzyme. Three factors determine the residual enzyme activity. First, as the OTC gene is carried on the X chromosome, a complete inactivation of this enzyme in a newborn boy results an acute ammonia intoxication. Second, the female mosaicism due to lyonization (differential randomized $\mathrm{X}$-inactivation) leads to differential OTC expression in hepatocytes. Third, the degree of severity depends on the mutation and the level of remaining activity it leaves to the protein. Published cases of OTC deficiency during pregnancy are scant. Most often, diagnosis of the metabolic disease is made before pregnancy or during the post-partum period

Methods

We report the case of a 22-year-old woman's successful pregnancy with a moderate form of ornithine transcarbamylase (OTC) deficiency, unsuspected before pregnancy, diagnosed by plasma aminoacidogram and orotic acid analysis, and initially masked by malnutrition

\section{Results - Conclusion}

Although maternal ammonia was subnormal and the neonate was safe, an OTC deficiency was revealed by stress analysis, fortunately did not prevent a successful pregnancy. Even if infrequent, this situation merits to be

\section{Key words}


82

83

84

85

86

87
The metabolism of nitrogen derived from protein intake and catabolic breakdown of endogenous protein is regulated by biochemical pathways that convert toxic ammonia into non toxic water-soluble urea which is released in the blood, and excreted by the kidneys. To ensure this nitrogen homeostasis, the complete urea cycle, strictly located in periportal hepatocytes, involves a series of four enzyme-mediated reactions that detoxify ammonia [1]. Transporters such as ornithine transporter-1 are also involved in the urea cycle (Figure 1).

Ornithine transcarbamylase (OTC) deficiency, though uncommon (estimated incidence: 1/14000), is the most frequent inborn urea cycle disorder (UCD) [2]. OTC catalyzes one of the mitochondrial steps of this cycle, transferring a carbamoyl group from the carbamyl-phosphate to ornithine to form citrulline, thus introducing the first nitrogen atom into the cycle. A scavenging pathway can also convert carbamyl-phosphate into orotate, an intermediate in pyrimidine base biosynthesis. Profiling plasma amino acid concentrations is the first step in diagnosing the malfunctioning enzyme in UCD, as summarized in Table I ; of note, variations of amino acids (e.g. alanine, lysine) are not systematically observed [3]. The citrullinemia values can be used in order to distinguish proximal from distal urea cycle deficiency. The citrullinemia levels are low in OTC and in carbamoyl phosphate synthetase (CPS-1) deficiency. Plasma concentration of arginine is reduced in every type of UCD, except in arginase deficiency, and are sometimes normal in late-onset or partial defects. Urine concentrations of orotic acid can help to distinguish between certain UCDs such as CPS-1 deficiency (low) and OTC deficiency (elevated) [4].

Symptoms and clinical presentations of OTC deficiency vary widely according to the remaining activity of the enzyme. Three factors determine the remaining enzyme activity. First, as the OTC gene is carried on the X chromosome, a complete inactivation of this enzyme in a newborn boy results in acute ammonia intoxication with digestive disorders, acid-base deregulation and progressive coma [5]. Second, the female mosaicism due to lyonization (differential randomized X-inactivation) leads to differential OTC expression in hepatocytes. Third, the degree of severity depends on the mutation and the level of remaining activity it leaves to the protein [4]. Hence partial deficiency of the urea cycle can leave the patient symptom-free, without hyperammonemia. Symptoms are delayed, usually triggered by metabolic decompensation related to high protein intake, acute catabolic stress or illness, such as sepsis, surgery, trauma, or drugs (e.g. valproic acid). In most of these episodes, patients can present with vomiting, loss of appetite, lethargy and neuropsychological abnormalities. Prompt recognition and treatment of these late-onset manifestations is crucial to improve the poor prognosis.

Published cases of OTC deficiency during pregnancy are scant. Most often, diagnosis of the metabolic disease is made before pregnancy or in the postpartum period. To our knowledge, the present case is one of only seven published reports of an OTC diagnosed in this setting (Table II) [6-11]. Hence despite specific guidelines [9], little is known about these patients. Mainly asymptomatic before pregnancy, all late-onset metabolic manifestations correspond to heterozygous mutation for the OTC gene. The common symptom shared by these heterozygous parturients seems to be disturbance of consciousness. Indeed, Schimanski et al. [11] suggest that OTC deficiency should be suspected in any hyperammonemic patient, albeit with normal hepatic function. 
The patient, a 22-year-old nulliparous woman, with an unremarkable medical history (including no documented intolerance or self-imposed dietary restriction), had been hospitalized seven times for uncontrollable cyclical vomiting from 9 weeks of gestation $(\mathrm{GW})$. The prescribed antiemetic medications, such as metoclopramide and ondansetron, were ineffective.

At $26 \mathrm{GW}$, the patient was admitted to the obstetric ward at Cochin Hospital for pelvic pains. She had received no prenatal care as a result of her precarious socioeconomic status.

On admission, the patient presented uncontrollable vomiting with hematemesis, esophagitis and gastritis, and deterioration of general status. She suffered from a severe hypokalemia $(1.8 \mathrm{mmol} / \mathrm{L})$, signs of discrete hepatic cytolysis (ASAT at $66 \mathrm{IU} / \mathrm{L}$ and ALAT at $48 \mathrm{IU} / \mathrm{L}$ ), dehydration and moderate-acute renal failure (creatinine clearance by the Cockroft-Gault formula at $49 \mathrm{~mL} / \mathrm{min}$ ).

She also presented psychomotor slow down and an episode of acute psychomotor agitation treated with chlorpromazine, with no underlying psychosis.

An echography showed an intrauterine growth restriction (IUGR) with a broken curve on cephalic and femoral parameters. Despite the risk of genetic abnormalities of the karyotype associated with IUGR, the patient refused amniocentesis.

For an unrecorded reason, a plasma aminoacidogram prescription was given at $26 \mathrm{GW}$ by a gastroenterologist. Amino acids were measured by ion exchange chromatography using an Aminotac instrument (Jeol, Japan). The assay revealed overall hypoaminoacidemia $(1551 \mu \mathrm{mol} / \mathrm{L}, \mathrm{N}: 2242-3610 \mu \mathrm{mol} / \mathrm{L})$ and a ratio of non-essential AAs to essential AAs close to 2 (Table III). Urinary aminoacidograms were also performed (Table IV).

At $29 \mathrm{GW}$, enteral nutrition by nasogastric tube was refused by the patient. At $30 \mathrm{GW}$, her weight had 144 decreased by $29 \%$ compared with pre-pregnancy weight. During progressive oral refeeding, from 29 to $32 \mathrm{GW}$, 145 the patient took two food supplements (Fortimel Compact Protein ${ }^{\circledR}$ ), with ingestas estimated at $1300 \mathrm{kcal} / \mathrm{day}$ including $450 \mathrm{kcal}$ of sodas according to the nutritionist ( $32 \mathrm{GW}$ ). At this moment, we did not knew that protein intake was deleterious ; anyway, dietitian mentioned that she did not take always the two food supplements (lack of compliancy? Hidden protein-intolerance?). Most amino acids returned to normal levels, except for citrulline, ornithine and arginine, which remained at low levels (Table III), suggesting a UCD. Moreover, a characteristic hyperorotaturia $(14.7 \mu \mathrm{mol} / \mathrm{mmol}$ of creatinine, $\mathrm{N}<6 \mu \mathrm{mol} / \mathrm{mmol}$ of creatinine) associated with mild hyperammonemia $(64 \mu \mathrm{mol} / \mathrm{L}, \mathrm{N}<26 \mu \mathrm{mol} / \mathrm{L})[12]$ at $34 \mathrm{GW}$ revealed an ornithine transcarbamylase (OTC)

152 deficiency. It was managed by initiation of parenteral nutrition and close ammonemia monitoring. 153 Administration of glucose $10 \%$ and Intralipid $20 \%$ was prescribed in order to forestall metabolic 154 decompensations. Some differential diagnosis, such as a mitochondrial disorder or abnormalities in the B155 oxydation, could be ruled out, since plasma lactate and plasma acyl-carnitine patterns were normal (data not 156 shown).

A severe sepsis occurred at $31 \mathrm{GW}$, involving the enterobacterium Klebsiella pneumomiae, an 158 opportunistic pathogen taking advantage of the physiological immunodepression associated with pregnancy [11]. 159 This infection was treated with antibiotics including gentamicin, amoxicillin, cefotaxime. Simultaneously, there 160 was a risk of pre-term delivery, addressed by Atosiban injection. A Clostridium difficile nosocomial infection 161 also occurred, which was treated with metronidazole. Also at $31 \mathrm{GW}$, the nutritional markers were decreased and 
the inflammation marker was increased (Table V).

163 The neonate was a premature hypotrophic boy $\left(1.4 \mathrm{~kg}\right.$ at birth at $32 \mathrm{GW},<97^{\text {th }}$ percentile). While 164 awaiting genetic confirmation, normal blood ammonia levels $(<94 \mu \mathrm{mol} / \mathrm{L})$ [13] during the first week, and 165 normal orotic acid urine levels $(2.5 \mu \mathrm{mol} / \mathrm{mmol}$ creatininuria) suggest that the neonate did not inherit the disease. 166 Finally, the newborn gained weight normally, and after one week, ammonia monitoring was stopped. Mother 167 and child were discharged one month after delivery.

\section{Discussion}

Here we report an OTC deficiency masked by hypoaminoacidemia that can be explained by either two hypotheses. The more consistent one is a state of malnutrition. However, despite knowledge of the consequences of malnutrition on both mother and child, few guidelines and little consensus have been established to estimate the exact nutritional status of pregnant women [14]. Biological markers such as albumin and transthyretin (prealbumin) are difficult to interpret. Albumin tends to decrease throughout pregnancy due to physiological haemodilution and a possible down-regulation of $\alpha$-foetoprotein on maternal albumin production [15]. Concerning transthyretin, the literature is conflicting: some authors report that transthyretin levels remained unchanged throughout pregnancy [16] while others found that they decreased [17]. Here, hypoalbuminemia and hypotransthyretinemia must be interpreted cautiously because of a biological inflammatory syndrome [18]. Hypoaminoacidemia could be caused by protein-energy malnutrition, due to decreased food intake and increased amino acid catabolism. Despite an initial severe obesity (BMI: $37.7 \mathrm{~kg} / \mathrm{m}^{2}$ ), the patient suffered an unintended loss of weight of more than 10\% in 6 months (usual pre-pregnancy weight: 87

$183 \mathrm{~kg}$; weight at $30 \mathrm{GW}: 62 \mathrm{~kg}$ ). This weight loss could have been caused by anorexia, nausea and vomiting during 184 pregnancy.

185 Another hypothesis is an excessive amino acid urinary loss. Indeed, a selective hyperaminoaciduria pattern evoked a Hartnup disorder (an inherited disorder of renal and intestinal amino acid transport [18], consistent with the patient's dermatitis and neurological problems. Organic kidney failure with tubulopathy (persistent proteinuria $>1 \mathrm{~g}$ per day, urinary ratio $\mathrm{Na} / \mathrm{K}<1$, B2-microglobulinuria at $200 \mu \mathrm{g} / \mathrm{g}$ creatinine) and urinary amino acid loss could also have contributed to amino acid blood depletion. This hypothesis could be ruled out since urinary amino acids levels returned partially to normal (Table IV) with refeeding and improvement of the patient's kidney function.

Little is known about the influence of malnutrition and pregnancy on the amino acid profile during OTC deficiency and the interaction between parameters could explain why the biological profile observed in our patient was atypical. Hypoaminoacidemia during pregnancy can be driven by three processes: lower protein catabolism, higher gluconeogenesis from amino acids and active transport through the placenta. Previous experimental [20] or clinical reports [21] found a selective hypoaminoacidemia (mostly concerning non-essential amino acids), whereas all amino acids were decreased in the present case.

Stress factors can trigger acute metabolic decompensations in the case of incomplete enzymatic deficiency with potentially lethal fetal hyperammonemic encephalopathy [8] which is explained by multiple biochemical disturbances in brain cells. The main features are edema, probably secondary to disruption of the 
aquaporin system and brain electrolyte homeostasis, increase in astrocytes glutamine synthesis, and swelling of astrocytes in response to the osmotic effect of glutamine, resulting in higher intracranial pressure [22].

In the present case, a remaining enzymatic activity could have prevented an acute metabolic decompensation that was triggered by hyperemesis, pregnancy and infection. The disease outcomes appear during decompensation episodes, thus contributing to a delayed diagnosis, from infancy to adulthood. The psychiatric symptoms mentioned might conceivably have resulted from a chronic moderate ammoniemic neurointoxication. Maternal vomiting, absent before the pregnancy continued after birth with severe hypokalemia, and might be possibly be linked to a psychiatric condition, with pathomimetic skin scratching, anxiety, obsessive-compulsive disorder and depressive syndrome. These symptoms are frequently described during the hyperemesis gravidarum syndrome [23], along with pernicious vomiting, hydroelectrolytic disorders or kidney damage. The moderate elevation of ammonia level can be explained by a detoxification by the healthy fetal liver [24], in addition to the increased nitrogenous conservation [25]. Though at risk of elevation due to the collagen breakdown theory during uterine involution, ammoniemia remained normal during post-partum period [26]. Indeed, catabolism of uterine extracellular matrix compounds, via metalloproteinase [27], releases nitrogen and permits the physiological post-partum involution (loss of size and weight).

The limitation of our study is that we were not able to get a genetical proof due to the lack of compliancy of the patient who refused repeatedly to consent to a genetic analysis. Another limitation is that the patient's protein intake during refeeding is not indicated in her files. However, measurement of plasma amino acids was performed at the post-absorptive state; therefore, protein intake did not affect the plasma amino acids pattern [28]. A third limitation is that we were unable to obtain a plasma aminoacidogram at discharge.

To sum up, OTC deficiency was masked in this case by hypoaminoacidemia and the relative normalization of amino acids levels with spontaneous refeeding, associated with persistent low citrulline and arginine levels, have revealed this urea cycle disorder. In conjunction with the amino acid profile, urinary orotate elevation, though unspecific, and hyperammonemia highlighted this OTC deficiency.

This form of enzyme deficiency, unsuspected before pregnancy, was revealed by stress factors - such as pregnancy itself, infection, uncontrollable vomiting, psychiatric syndromes - and was masked by malnutrition. However, this metabolic disease, revealed by aminoacidogram and urine orotic acid analysis, fortunately did not prevent a successful pregnancy.

Statement of authorship

Bertrand Lefrère: writing, data curation, formal analysis, investigation

Guillaume Ulmann: data curation, formal analysis, investigation

Mélanie Chartier: clinical management, review

Juliana Patkai: clinical management, review

Nathalie Neveux: conceptualization, data curation, formal analysis, investigation

Luc Cynober: formal analysis, review

\section{Conflicts of interest statement: none}

\section{Funding sources: none}




\section{References}

251

252

253

254

255

256

257

258

259

260

261

262

263

264

1. Cynober L. Amino acid metabolism. In : Encyclopedia of Biological Chemistry, 2004, vol 1. Elsevier Inc, New-York, p 90-95.

2. Ituk U, Constantinescu OC, Allen TK, Small MJ, Habib AS. Peripartum management of two parturients with ornithine transcarbamylase deficiency. Int J Obstet Anesth. $2012 ; 21 ; 90-93$.

3. Rodney S, Boneh A. Amino Acid Profiles in Patients with Urea Cycle Disorders at Admission to Hospital due to Metabolic Decompensation. JIMD Rep 2013; 9: 97-104

4. Machado MCC, da Silva FP. Hyperammonemia due to urea cycle disorders: a potentially fatal condition in the intensive care setting. J Intens Care 2014, 2:22-26.

5. Batshaw ML, MacArthur RB, Tuchman M. Alternative pathway therapy for urea cycle disorders: Twenty years later. J Pediatr. $2001 ; 138 ; 46-55$.

6. Bailly P, Noury JB, Timsit S, Ben Salem D, Teaching Neuro Images : Ornithine transcarbamylase deficiency revealed by a coma in a pregnant woman. Neurology. $2015 ; 85 ; 146-147$.

7. Nakajima H, Sasaki Y, Maeda T, Takeda M, Hara N, Nakanishi K, Urita Y, Hattori R, Miura K, Taniguchi T. Antepartum Ornithine Transcarbamylase Deficiency. Case Rep Gastroenterol. 2014 ; 8; 337345.

8. Celik O, Buyuktas D, Aydin A, Acbay O. Ornithine transcarbamylase deficiency diagnosed in pregnancy. Gynecol Endocrinol. $2011 ; 27 ; 1052-1054$.

9. Mendez-Figueroa H, Lamance K, Sutton V, Aagaard-Tillery K, Van den Veyver I. Management of Ornithine Transcarbamylase Deficiency in Pregnancy. Am J Perinatol. 2010; 27; 775-784.

10. Quintero-Rivera F, Deignan JL, Peredo J, Grody WW, Crandall B, Sims M, Cederbaum SD; An exon 1 deletion in OTC identified using chromosomal microarray analysis in a mother and her two affected deceased newborns: Implications for the prenatal diagnosis of ornithine transcarbamylase deficiency. Mol genet metab. $2010 ; 101 ; 413-416$.

11. Schimanski U, Krieger D, Horn M, Stremmel W, Wermuth B, Theilmann L. A novel two-nucleotide deletion in the ornithine Transcarbamylase gene causing fatal hyperammonia in early pregnancy. Hepatology. 1996 ; 24; 1413-1415.

12 Mor G, Cardenas I. The Immune System in Pregnancy: A Unique Complexity. Am J Reprod Immunol. 2010 Jun; 63(6): 425-433.

13. Adam MP, Ardinger HH, Pagon RA, et al., editors. Seattle (WA): University of Washington, Seattle; 1993-2018.

14. Ververs M, Antierens A, Sackl A, Staderini N, Captier V. Which Anthropometric Indicators Identify a Pregnant Woman as Acutely Malnourished and Predict Adverse Birth Outcomes in the Humanitarian Context? PloS Curr. 2013;5: ecurrents.

15. Maher JE, Goldenberg RL, Tamura T, Cliver SP, Hoffman HJ, Davis RO, Boots L. Albumin levels in pregnancy: a hypothesis - decreased levels of albumin are related to increased levels of alpha-fetoprotein. Early Hum Dev. 1993; 34; 209-215.

16. Giacoia JP. Concentration of serum prealbumin and retinol-binding proteins during pregnancy. South med J. 1984; 77; 1261-1263.

17. Edwards CL, Novotny R, Claybaugh J, Weems C. Serum prealbumin decreases during pregnancy. $J$ Acad Nutr Diet. 1998 ; 98: A57.

18. Dellière S, Cynober L. Is transthyretin a good marker of nutritional status? Clin Nutr, 2017 ; 36: 364370 .

19. Bröer S, Cavanaugh JA, Rasko JE. Neutral amino acid transport in epithelial cells and its malfunction in Hartnup disorder. Biochem Soc Trans. 2005; 33:233-6.

20. Palou A, Arola L, Alemany M. Plasma amino acid concentrations in pregnant rats and in 21-day foetuses. Biochem J. 1977 ; 166; 49-55.

21. Di Giulio A, Carelli S, Castoldi R, Gorio A, Taricco E, Cetin I. Plasma amino acid concentrations throughout normal pregnancy and early stages of intrauterine growth restricted pregnancy. J Matern Fetal Neonatal Med. 2004; 15; 356-362.

22. Brusilow SW, Koehler RC, Traystman RJ, Cooper AJ: Astrocyte glutamine synthetase: importance in hyperammonemic syndromes and potential target for therapy. Neurotherapeutics 2010, 7:452-470

23. Tan PC, Zaidi SN, Azmi N, Omar SZ, Khong SY. Depression, Anxiety, Stress and Hyperemesis Gravidarum: Temporal and Case Controlled Correlates. PloS One. 2014 ; 17; 9 . e92036.

24.Arn H, Hauser ER, Thomas GH, Herman G, Hess D, Brusilow SW. Hyperammonemia in women with mutation at the ornithine carbamoyltransferase locus : a cause of postpartum coma. New Eng J Med. 1990 ; $322 ; 1652-1655$. 
306

307

308

309

310

311

312

313

314

315

316

317

318

319

320

321

322

323

324

325

326

327

328

329

330

331

332

333

334

335

336

337

338

339

340

341

342

343

344

345

346

347

348

349

350

351

352

353

354

355

356

357

358

359

360

361

362

363

364

365
25. Lamb S, Aye CYL, Murphy E, Mackillop L. Multidisciplinary management of ornithine transcarbamylase (OTC) deficiency in pregnancy: essential to prevent hyperammonemic complications. BMJ Case Rep. 2013;10.1136/bcr-2012-007416.

26. Belstra BA, Flowers WL, Croom WJ, DeGroot J, See MT. Urinary excretion of collagen degradation markers by sows during postpartum uterine involution. Anim Reprod Sci. 2005; 85; 131-145.

27. Manase K, Endo T, Chida M, Nagasawa K, Honnma H, Yamazaki K, Kitajima Y, Goto, T, Kanaya M, Hayashi T, Mitaka T, Hayashi T. Coordinated elevation of membrane type 1-matrix metalloproteinase and matrix metalloproteinase-2 expression in rat uterus during postpartum involution. Reprod Biol Endocrinol. $2006 ; 4 ; 32$.

28. Cynober L. Plasma amino acid levels with a note on membrane transport: characteristics, regulation, and metabolic significance. Nutrition 2002; 18: 761-766.

29. Neveux N, David P, Cynober L. Measurement of amino acid concentration in biological fluids and tissues using ion-exchange chromatography. In:Cynober LA Ed. Metabolic and Therapeutic Aspects of Amino Acids in Clinical Nutrition, second edition. CRC Press, Boca Raton, FL, 2003 : pp. 17-28. 


\begin{tabular}{ccccccc}
\hline UCD & Protein involved & Ala & Arg & Lys & Orn & \\
& & $286-416$ & $60-80$ & $156-220$ & $39-74$ & Urinary orotate \\
\hline OTC & Ornithine transcarbamoylase & $\uparrow$ & $\downarrow$ & $\uparrow$ & $\downarrow$ & $\downarrow$ \\
NAGS & N-Acetylglutamate synthetase & $\uparrow$ & $\downarrow$ & $\uparrow$ & $\uparrow$ & $\downarrow$ \\
CPS & Carbamoyl phosphate synthetase & $\uparrow$ & $\downarrow$ & $\uparrow$ & N or $\downarrow$ \\
HHH & Mitochondrial ornithine transporter 1 & $\uparrow$ & $\downarrow$ & $\mathrm{N}$ or $\downarrow$ & $\mathrm{N}$ or $\uparrow$ \\
P5CS & Pyrolline-5-carboxylate synthetase & $\mathrm{N}$ & $\downarrow$ & $\mathrm{N}$ & $\downarrow$ & $\mathrm{N}$
\end{tabular}

372

373

374

375

376

377

378

379

380

381

382

383

384

$385 \quad$ Adapted from [3]

386 Ala: alanine; Cit : citrulline; Arg: arginine

387 N: normal

388 HHH: Hyperornithinemia - Hyperammonemia - Homocitrullinemia

$389 \mathrm{~N}$ : normal ; $\uparrow:$ increased compared to normal value :; $\downarrow$ decreased compared to normal value. 


\section{Table II. Literature review of late-onset OTC deficiency diagnosed during pregnancy or shortly post-partum.}

Authors Age and GW

Clinical outcomes

\begin{tabular}{ccl}
$\begin{array}{c}\text { Bailly } \\
\text { [6] }\end{array}$ & 32 & $\begin{array}{l}\text { - progressive neuropsychological and behavior disorders, coma } \\
\text { - improvement of consciousness with therapy, but persistent mild }\end{array}$ \\
& G1, P1 & $\begin{array}{l}\text { cognitive impairment persistent } \\
\text { - female infant had no sequelae at 11 months }\end{array}$ \\
\hline $\begin{array}{c}\text { Nakajima } \\
\text { [7] }\end{array}$ & 28 & $\begin{array}{l}\text { - chief complaint: disturbance of consciousness } \\
\text { - hyperemesis gravidarum }\end{array}$ \\
& G1 &
\end{tabular}

\begin{tabular}{ccl}
\hline Celik & 31 & - admission for mental confusion \\
{$[8]$} & G1, P2 & - epileptic seizures for 15 years, \\
& - vaginal delivery of a viable, unaffected male infant \\
\hline Uncertain & $\begin{array}{l}\text { - two maternal half- sisters found to be OTC deficiency carriers } \\
\text { G2, P1 }\end{array}$ & $\begin{array}{l}\text { diet } \\
\text { - the patient remained asymptomatic postpartum }\end{array}$
\end{tabular}

Mendez-

Figueroa

35

[9] $\quad$ G2, $\mathrm{P} 0$

- positive family history of OTC deficiency

- lifelong history of migraine headaches after high-protein meals

- vaginal delivery a viable female infant

36 - gestational diabetes

G1 - vaginal delivery of a viable male infant

- postpartum day 3: hypoxic episode for the infant

18

- preterm premature rupture of membranes

- nausea and vomiting early in pregnancy

- forceps-assisted vaginal delivery

- postpartum day 8: lethargic infant

\begin{tabular}{ccl}
\hline $\begin{array}{c}\text { Quintero- } \\
\text { Rivera } \\
{[10]}\end{array}$ & G1, P0 & $\begin{array}{l}\text { - self-chosen vegetarian diet } \\
\text { - mother and two male infants died of OTCD }\end{array}$ \\
\hline $\begin{array}{c}\text { Shimanski } \\
{[11]}\end{array}$ & 2410 & - hyperemesis gravidarum, severe malnutrition \\
\hline
\end{tabular}

Biology

- Biochemistry: hyperammonemia (173 $\mu \mathrm{mol} / \mathrm{L})$, glutamine chromatographic peak, increased urinary orotate excretion

- DNA analysis: novel heterozygous mutation c.626C>A/p.Ala209Glu in $O T C$ gene for both mother and female infant

- Biochemistry: hyperammonemia at admission: $268 \mu \mathrm{mol} / \mathrm{L}$; Gln elevated, Cit, Orn,
Arg low, high orotic acid excretion

- DNA analysis: OTC mutation (829 C >T/R277W)

c. $829 \mathrm{C}>\mathrm{T} / \mathrm{p}$.Arg277Trp

- Biochemistry: hyperammonemia $(179 \mu \mathrm{mol} / \mathrm{L})$, normal plasma aminoacidogram, increased urinary orotate excretion

- DNA analysis: heterozygous for three polymorphisms (K46R, Ivs3-8A4 T, Q27OR)

- Biochemistry: prenatal and postpartum serum amino acid profiles all within normal limits. Ammonia levels remained within normal limits, except for one value after an unauthorized snack

- DNA analysis: heterozygous c.122A $>\mathrm{G}$ (p.D41G) mutation for both mother and male fetus c.122A $>$ G/p.Asp41Gly

- Biochemistry: ammonia level of $98 \mu \mathrm{mol} / \mathrm{L}$ on admission for induction of labor, levels then remained normal 4 months postpartum.

- DNA analysis: heterozygous OTC mutation for the mother

- Biochemistry: all results at admission within normal limits, but serum ammonia level not obtained. Hyperammonemia in postpartum.

- DNA analysis: c.122A>G (p.D41G) mutation for the mother

c. $122 \mathrm{~A}>\mathrm{G} / \mathrm{p}$. Asp41Gly

- Biochemistry: hyperammonemia for the infant at day 2

- DNA analysis: hemizygous mutation c.904C > T (p.H302Y) for both mother and infant c. 904 C $>$ T/p.Cys302Tyr

- One infant was demonstrated likely to be OTC deficient.

- DNA analysis: exon 1 deletion of $O T C$ gene

- Biochemistry: hyperammonemia $(380 \mu \mathrm{mol} / \mathrm{L})$, massive excretion of orotic acid, normal OTC activity in biopsy - DNA analysis: deletion T892 and G893 of OTC gene 
Table III. Plasma amino acids ( $\mu \mathrm{mol} / \mathrm{L})$ at admission (25 GW) and during hospitalization

\begin{tabular}{|c|c|c|c|c|c|c|}
\hline Amino acid & $25 \mathrm{GW}$ & 29 GW & $30 \mathrm{GW}$ & 31 GW & 32 GW & $\begin{array}{l}\text { Reference } \\
\text { range [29] }\end{array}$ \\
\hline Taurine & 45 & 49 & 89 & 56 & 78 & $42-68$ \\
\hline Aspartic acid & 3 & 4 & 7 & 4 & 5 & $2-14$ \\
\hline Hydroxyproline & 24 & 38 & 55 & 59 & 72 & $0-37$ \\
\hline Threonine & 95 & 121 & 115 & 100 & 140 & $107-173$ \\
\hline Serine & 75 & 119 & 123 & 117 & 135 & $95-133$ \\
\hline Asparagine & 29 & 48 & 49 & 54 & 63 & $36-60$ \\
\hline Glutamic acid & 37 & 78 & 59 & 45 & 64 & $30-80$ \\
\hline Glutamine & 415 & 590 & 595 & 630 & 616 & $500-670$ \\
\hline Proline & 104 & 183 & 297 & 300 & 322 & $108-228$ \\
\hline Glycine & 139 & 219 & 253 & 221 & 278 & $178-282$ \\
\hline Alanine & 189 & 225 & 507 & 405 & 308 & $286-416$ \\
\hline Citrulline & 6 & 6 & 6 & 8 & 11 & $30-46$ \\
\hline 2-Aminobutyric acid & 4 & 7 & 8 & 8 & 9 & $9-29$ \\
\hline Valine & 75 & 93 & 75 & 87 & 102 & $190-276$ \\
\hline Cystine & 13 & 15 & 26 & 15 & 22 & 55-109 \\
\hline Methionine & 11 & 10 & 14 & 12 & 15 & $21-29$ \\
\hline Isoleucine & 22 & 18 & 26 & 18 & 27 & $48-76$ \\
\hline Leucine & 37 & 46 & 42 & 46 & 53 & $98-148$ \\
\hline Tyrosine & 22 & 17 & 25 & 20 & 25 & 47-71 \\
\hline Phenylalanine & 26 & 31 & 33 & 32 & 36 & $48-66$ \\
\hline Ornithine & 19 & 13 & 18 & 13 & 18 & $39-74$ \\
\hline Lysine & 75 & 114 & 82 & 98 & 108 & $156-220$ \\
\hline Histidine & 51 & 70 & 69 & 63 & 86 & $72-92$ \\
\hline 3-Methylhistidine & 2 & 3 & 2 & 4 & 3 & $1-5$ \\
\hline Tryptophane & 16 & 5 & 9 & 4 & 8 & $10-40$ \\
\hline Arginine & 17 & 18 & 15 & 15 & 19 & $60-80$ \\
\hline Total aminoacidemia & 1551 & 2140 & 2599 & 2434 & 2623 & $2242-3610$ \\
\hline
\end{tabular}


Table IV. Urinary aminoacidogram

\begin{tabular}{|c|c|c|c|c|}
\hline $\begin{array}{l}\text { Amino acid }(\mu \mathrm{mol} / \\
\text { creatinine }(\mathrm{mmol})\end{array}$ & 29 GW & $30 \mathrm{GW}$ & 31 GW & $\begin{array}{c}\text { Reference } \\
\text { range [29] } \\
(\mu \mathrm{mol} / \mathrm{mmol})\end{array}$ \\
\hline Taurine & 16 & 17 & 23 & $16-180$ \\
\hline Hydroxyproline & 3 & 2 & 2 & $<13$ \\
\hline Threonine & 186 & 22 & 40 & $7-29$ \\
\hline Serine & 381 & 75 & 122 & $21-50$ \\
\hline Asparagine & 183 & 17 & 46 & $<23$ \\
\hline Glutamate & 1 & 4 & 4 & $<12$ \\
\hline Glutamine & 509 & 70 & 134 & $20-76$ \\
\hline Proline & 1 & 4 & 32 & $<9$ \\
\hline Glycine & 764 & 273 & 517 & $43-173$ \\
\hline Alanine & 76 & 69 & 129 & $16-68$ \\
\hline Citrulline & 0 & 0 & 0 & $<4$ \\
\hline 2-Aminobutyric acid & 4 & 2 & 32 & $<4$ \\
\hline Valine & 9 & 3 & 4 & $3-13$. \\
\hline Cystine & 5 & 6 & 4 & $6-34$ \\
\hline Methionine & 3 & 4 & 5 & $2-16$ \\
\hline Isoleucine & 3 & 2 & 2 & $<4$ \\
\hline Leucine & 10 & 3 & 3 & $2-11$ \\
\hline Tyrosine & 29 & 10 & 14 & $2-23$ \\
\hline Phenylalanine & 18 & 6 & Interference* & $2-19$ \\
\hline Ornithine & 4 & 0 & 1 & $<5$ \\
\hline Lysine & 30 & 4 & 8 & $7-58$ \\
\hline Histidine & 453 & 99 & 189 & $26-153$ \\
\hline 3-Methylhistidine & 38 & 24 & 8 & $19-47$ \\
\hline Arginine & 1 & 1 & 1 & $<5$ \\
\hline Total aminoaciduria/creatinine & 2718 & 717 & 1320 & \\
\hline
\end{tabular}

\footnotetext{
* Likely by antibiotics
} 
Table V. Biological nutritional assessment at 31 GW

\begin{tabular}{|c|c|c|}
\hline & Level & Reference range \\
\hline Albuminemia & $22 \mathrm{~g} / \mathrm{L}$ & $38-48 \mathrm{~g} / \mathrm{L}$ \\
\hline Transthyretinemia & $0.10 \mathrm{~g} / \mathrm{L}$ & $0.18-0.45 \mathrm{~g} / \mathrm{L}$ \\
\hline CRP & $40 \mathrm{mg} / \mathrm{L}$ & $<5 \mathrm{mg} / \mathrm{L}$ \\
\hline
\end{tabular}


Figure 1. Periportal hepatocyte ureogenesis: a simplified view of the urea cycle

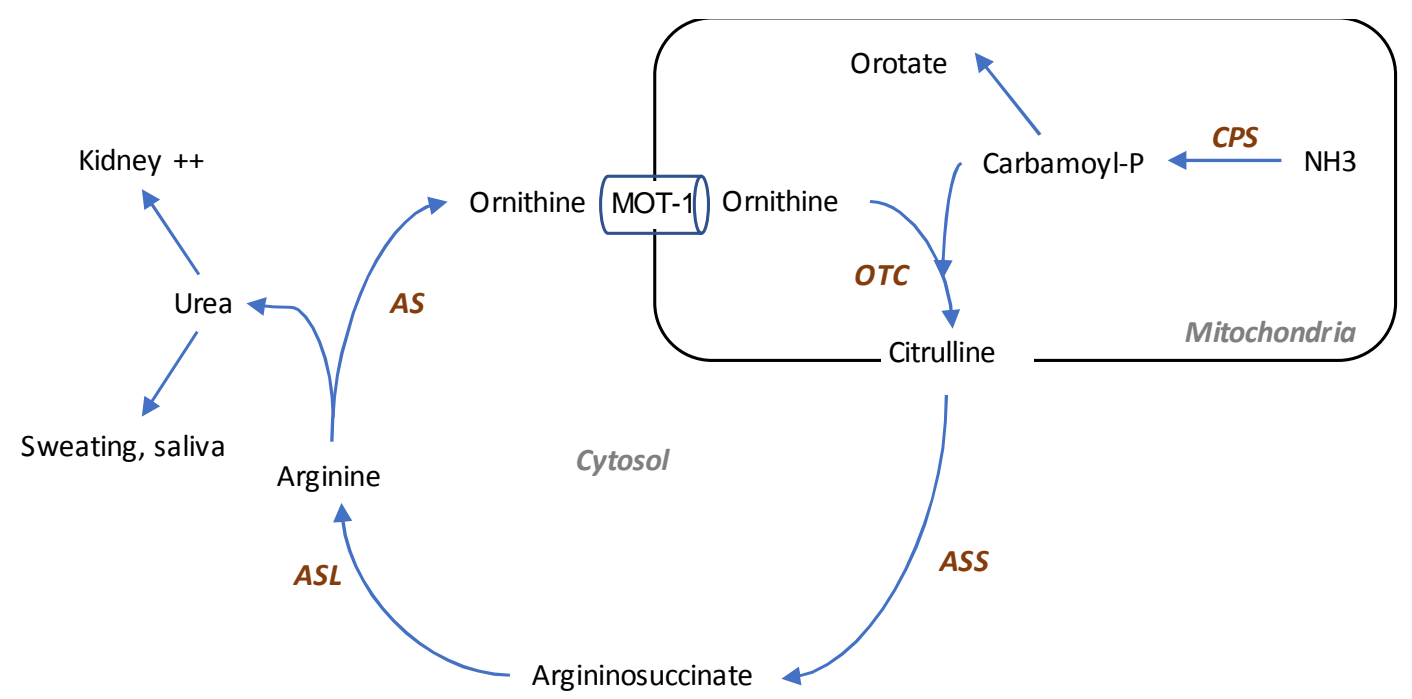

CPS : Carbamyl phosphate synthetase

OTC : Ornithine transcarbamoylase

ASS : Argininosuccinate synthetase

$A S L$ : Argininosuccinate lyase

$A S:$ Arginase

MOT-1 : Mitochondrial ornithine transporter 1 